Anna-Marie de Beer \&

Elisabeth Snyman

Anna-Marie de Beer teaches in French in the Department of Modern European

Languages, University of Pretoria.

Email: annamarie.debeer@up.ac.za

Elisabeth Snyman is a Professor in

French at the School of Languages of the

North-West University, Potchefstroom.

Email: elisabeth.snyman@nwu.ac.za

\title{
Shadows of life, death and survival in the aftermath of the Rwandan genocide
}

\section{Shadows of life, death and survival in the aftermath of the Rwandan genocide}

Various writers and survivors have offered literary responses to the genocide of the Tutsi in Rwanda. In 1998, a group of African intellectuals, mostly non-Rwandans, of whom two were female authors, participated in a collective writing project, Rwanda: écrire par devoir de mémoire, tasked to tell the story of the genocide. Genocide survivor, sociologist and psychotherapist, Esther Mujawayo, has since narrated her own story. Although critics have explored the portrayal of trauma in literature in other texts and contexts, a comparative study between these three texts of female authors; one survivor and two intellectuals, focusing on the experience of female survivors and in particular that of being raped has not yet been conducted. This article examines how trauma is made visible to the reader by exploring the characteristics of the 'death experience' and their mediated form, as offered by the three authors. This comparative study furthermore highlights the elements in the lives of survivors which influence their ability to move from a position of mere survival to that of embracing life after the genocide. Keywords: devoir de mémoire, Esther Mujawayo, female survivor, Monique Ilboudo, rape, representation of trauma, Rwandan genocide, testimony, Véronique Tadjo.

Tutsi survivor, Esther Mujawayo, assures us that genocide does not consist of "only one type of violence. It's not only the violence of death or physical torture. It destroys you from within, it makes of you what the other wants you to be: nothing, even less than nothing. Even while alive, you cease to exist." $(153)^{1}$

Initially, Western writers and journalists were amongst the first to respond to the 1994 genocide of the Tutsi in Rwanda, but in 1998 a group of African intellectuals, most of them not victims or eyewitnesses themselves, took up the task of writing about the genocide. These African authors, involved in the collective literary project entitled Rwanda: écrire par devoire de mémoire, aimed to act as precursors, encouraging Rwandans to narrate their own experiences. ${ }^{2,3}$ One of the first survivors to take up this challenge, albeit in collaboration with journalist Souâd Belhaddad, was sociologist and psychotherapist Esther Mujawayo. This article then considers the process of the portrayal of trauma initiated by two African woman writers from this project, considered to be "intellectual witnesses", and continued by a third, a Tutsi survivor. Our discussion compares varying strategies of representation of the same historical event, always bearing in mind that the first two are works of fiction based on the 
historical reality of the genocide, whereas Mujawayo's text is a testimony. We show how the work of the three authors under investigation forms part of a continuum, with the literary configurations preceding the biographical. Monique Ilboudo from Burkina Faso and Véronique Tadjo from Côte d'Ivoire, who travelled to Rwanda four years after the genocide, were already accomplished writers at the time. For Esther Mujawayo, SurVivantes was her first text. ${ }^{5}$

One of the main aspects that these accounts have in common are their concern with quality of life after the genocide, and they all engage with the issues of death, life and survival, which also constitutes the main concern of this article. On the first page of her testimony, Mujawayo (5) writes: "I do not know if my reaction comes from pride or if it's a survival instinct. I know only this; that to be fully alive rather than to survive, is a way of punishing them. It's the only revenge possible to me $e^{\prime \prime}{ }^{6}$ In her text, Murekatete, Monique Ilboudo (12) creates a main character whose father gave her "a dream of a name: Murekatete", which means "let her live! Let her be comfortable!" This text portrays the character's attempt to work through the genocide experience in order to embrace life and to be what Mujawayo (223) calls vivante-vivante instead of mort-vivant. However the literary character will remain caught up in her own failed narrative of one who has survived, yet cannot integrate the past into her present. Véronique Tadjo, in her account of the genocide entitled L'ombre d'Imana: voyages jusqu'au bout du Rwanda, creates female protagonists whose experiences embody the violence inherent in genocide: these women are raped, widowed, betrayed, bereaved, maimed and devalued; and are obliged to revert to a variety of strategies of survival. Tadjo points out how they die over and over again. These texts configure how genocide has impacted the lives of individuals, their capacity to and at times their inability to overcome the trauma they have lived through. Our analysis of Mujawayo's text focuses on the real-life strategies she employed to help her work through her trauma, whereas for the other two authors, more attention is paid to how they portray the paralysing effect of the 'death experience'.

\section{Trauma, memory and death}

The two central theoretical tenets that inform this discussion are the processes of transforming traumatic memory into narrative memory, and the role of an appropriate listener in these processes. Depending on the context, the listener can be located in the community who supports the survivor, in the author recording the narrative, or in the reader.

Let us consider first the notion of traumatic memory, and in particular the 'death' experience of survivors, which does not refer to physical death, but to what Ursula Tidd (408), has called the "lived experience of this dying permeating life". We then examine the role of the listener, as well as restorative possibilities embedded in the 
process of narration. Finally, these observations will be contextualised within the experiences depicted or imagined in the three texts mentioned.

The experience of trauma, which is often described as a form of 'dying' by trauma survivors, takes on various guises: one of its manifestations is the fracturing or multiplication of the self during which a victim "creates a second 'self' due to conflict in the 'original self'" (Tidd 408, 412). This strategy enables the victim to create a distance from the traumatising experience. Severe trauma has been described as "the undoing of the self" which includes a breakdown in trust, and emotional numbness (Brison $40,44)$. When trauma is intentionally inflicted by another, it undoes the "sustaining connection between the self and the rest of humanity", as victims are often reduced to objects, a process which damages their subjectivity (Brison 40). Judith Herman (53) notes that the traumatic event "destroys the belief that one can be oneself in relation to others" and Susan Brison (41) concurs that "without this belief one can no longer be oneself even to oneself, since the self exists fundamentally in relation to others." Trauma can thus be seen as a form of "shattering" or "figurative dismemberment", a disintegration of the self and of its relation to others, to time and to memory, disrupting "the ongoing narrative, severing the connections among remembered past, lived present, and anticipated future" (Brison 41,48). The victim experiences a loss of sense of control over the events and consequently of herself and eventually feels alienated from herself. This in turn leads to the loss of motivation to reconstruct the narrative that has been disrupted by trauma (Brison 44). Furthermore, traumatic memory blurs the distinction between body and mind, so that mental trauma often manifests as physical symptoms and sensory flashbacks (Brison 42, 43).

A traumatic experience is commonly referred to as that which is indicible ("the unspeakable") or invivable ("that which is impossible to live/unbearable"). These terms point to limits both in representing and experiencing such an event and reiterate the question posed by Ursula Tidd (407): "Can one bear witness to death or is it an epistemological and empirical void?" Holocaust survivor, Jorges Semprun (26), evokes the enigmatic concept described by many survivors, of avoir traversé la mort ("passing through death"). ${ }^{7}$ He refers to himself not as a survivor, but as a revenant, one who has literally returned from the dead (Semprun121). Charlotte Delbo (66) writes: Je suis morte à Auschwitz, et personne ne le voit ("I died at Auschwitz, but no one knows it"), and Semprun (121) confirms that death is not something that they "came close to" and from which they "escaped, like an accident from which one came out unscathed"; it was something they "lived". ${ }^{8}$

The term indicible, evokes limits related to social constraints and the inability to transmit the experience to others. The experience of "passing through death", which is in a sense an 'impossible' experience (invivable) cannot be fully expressed within the narrative convention available to us and therefore becomes the indicible (Van Alphen 35). This death experience can only be uttered "in an abstract way" (abstraitement) for 
as Semprun notes, it is "not believable, difficult to share and hardly comprehensible" (Car ce n'est pas crédible, ce n'est pas partageable, à peine comprehensible, 121). ${ }^{9}$

Semprun is also painfully aware of the (in)capacity of the listener to appropriate the articulated experience to which he/she has access only through language. This aspect complicates the process of sharing trauma with the other: "Everything can be said, language contains everything [...] One can tell everything about this experience [...] But can one hear all of it, imagine it all? [...] Will they have the patience, the passion, the compassion, the necessary rigour?" (Semprun 26$) \cdot{ }^{10}$ Mieke Bal notes that traumatic memory has "no social component" as it is not addressed to anybody (Bal, Crewe and Spitser $\mathrm{x}$ ). It is a solitary event which is a "(non)memory" in a sense because the subject lacks the "narrative mastery" over it, whereas narrative memory is a social construction, which comes about in a "cultural context" and usually offers some form of feedback by another who can respond with horrified understanding and who acts as "confirming witness" (Bal, Crewe and Spitser $\mathrm{x}$ ). The ability to remember traumatic events is influenced then by not only how the victim experiences them, but also how others perceive them (Brison 43). Furthermore, the other, who bears witness to the trauma through listening, profoundly influences the whole "possibility of telling the horror" (Bal, Crewe et Spitser x).

It is commonly accepted today that narrative integration of a traumatic experience contributes to the process of recovery (Herman 1; Brison 40). However, such narration, if it indeed takes place, is often "fragmented" and "contradictory" and traumatic experiences are more likely to be expressed in terms of nightmares or hallucinations, intrusive flashbacks and re-enactments, "vivid sensations and images", associated with the Freudian concept of 'acting out' (Herman 38; Caruth 4). According to contemporary theories (Van der Kolk \& Van der Hart 160-3), traumatic memories are not structured in the conventional linear, narrative fashion in which 'normal' memories are encoded. Although these "images of traumatic re-enactment" are very detailed and precise, they are for the most part not accessible to the victim in terms of "conscious recall and control" in order to be readily integrated into a story of the past (Caruth 151). Narrative integration helps the survivor not only to restore the subversion of the time sequence brought about by trauma, but also to start mastering the return of intrusive memories (Brison 46). Moreover, the verbalisation of the traumatic event has the potential to assist in "reintegrating the fractured selves" that were created during the event (Tidd 412).

\section{'Remaking' the self}

If the 'death' experiences that Mujawayo, Delbo, Semprun and other survivors speak of can therefore be described as an "undoing" and "fracturing" of the self, Brison's interest is in the process of "remaking" the self, and re-establishing a relationship 
with the other through narrative (45). A listener who has the strength, patience and compassion to hear and understand the story, an 'other' whom Dori Laub (73) calls an "authentic", "suitable" listener is essential in this process. Roberta Culbertson (179) who focuses on the sensory and bodily aspects of trauma describes the process of recovery as follows: "To return fully to the self as socially defined, to establish a relationship again with the world, the survivor must tell what happened. This is the function of narrative. The task then is to render body memories tellable, which means to order and arrange them in the form of a story [...]."

As will be seen in our analyses, these two processes are embodied in the texts under discussion: Ilboudo and Tadjo use literary devices to evoke the physical and emotional effects of trauma in their characters, whereas Mujawayo, the real-life victim, goes a step further by recording her own process of "remaking" of the self and the reestablishment of relationships with the community.

Brison argues that contrary to the involuntary and intrusive nature of traumatic memories, narrative memory can be empowering in the sense that it is a voluntary act, chosen and not inflicted or endured. These narrations, or "speech acts of memory" (39) can "defuse" traumatic memory, "giving shape and a temporal order to the events recalled, establishing more control over their recalling, and helping the survivor to remake a self" (40). This process involves "regaining one's voice" and subjectivity after being silenced, and a shift from being the object or medium of someone else's words or behaviour to being the "subject of one's own" (Brison 39, 48). This can be made possible by telling one's narrative to another who cares to listen. Thus in transforming traumatic memory into "a coherent narrative that can then be integrated into the survivor's sense of self and view of the world" (Brison 39), the survivor can be reintegrated into a community. It seems that the two literary narratives under discussion show the way of how to create such narratives, whilst refraining from speaking on behalf of the victim, whereas the non-literary account is an example of such a narrative by a victim.

One form of 'dying' that is strongly associated with the genocide of the Tutsi in Rwanda, is the experience of being raped. ${ }^{11}$ Mujawayo (196-7) notes that during a study performed by an association for women in Rwanda, focusing on the "taboo" topic of rape, it was found that eighty per cent of the female survivors had been raped and more than half of them infected with AIDS. Although a word for this crime had not existed in this society before the genocide, the term kubohoza, to "liberate" through violence (libérer, 195), became a common word for it, because of its use by perpetrators: "We have liberated those Tutsi women, we have liberated those arrogant ones..." (196). ${ }^{12}$ The investigators identified psychological and physical symptoms endemic to rape survivors, such as a tremendous fatigue, constant back ache and headaches, memory loss, incessant anguish, hallucinations, insomnia and nightmares, and a large amount of survivors were haunted by the impression of being insane (Mujawayo 
and Belhaddad, 203, 207). Mujawayo points out that for these women, although often paradoxically, being raped had saved them from being killed, they emerged from the horrors of the experience reluctantly, because they now had to live through a "hell worse than death" (un enfer pire que la mort, 197). They had been left alive by the perpetrators "so that there would be no point in surviving", (pour que survivre ne leur ait servi à rien) because they would be living a "continual death" (une mort continue, 197). As will be seen below, Mujawayo's description of this "continual death" encompasses both its psychological and physical manifestations.

A closer reading of our three texts reveals the textual strategies which render signs of trauma, with particular reference to the experience of the "undoing" and the "remaking" of the self. Various descriptions of the rape of Tutsi victims during the genocide exist in genocide narratives, and this act has long been acknowledged as one of the 'weapons' of the genocide. It is interesting however, that in both literary extracts that we discuss here, chosen for their portrayal of the effects of trauma, the rape incidents do not take place during the genocide and neither of them is in fact committed by Hutu perpetrators. It seems that the authors of the two literary texts have placed their narrations of rape in contexts which endow them with additional metaphorical meaning: Tadjo's character is raped before the genocide by her own brother, and this event seemingly has no obvious relation to the genocide. It soon becomes clear however that the author thus metaphorically evokes one of the most problematic features of the genocide, namely that family members found themselves in opposing camps and that victims were often betrayed by those closest to them. The author subtly accentuates this closeness by her choice of a mirror name for brother and sister: Anastase and Anastasie. Ilboudo's female character is raped after the genocide by her own husband, and it is clearly a secondary effect of the genocide on their lives, underlining the prolonged effects of trauma which are not confined to the period of the genocide.

\section{Murekatete: a narrative of death}

The life of the main character in Monique Ilboudo's novel, Murekatete, is a painful contrast to the life-affirming name bestowed on her by her father, whose choice of name demonstrates his belief in her capacity to survive, his love for her and his "determination" to protect her against everything and everybody (Ilboudo 12). Ironically, her life becomes a battle against death, the death of her beloved father, her husband, her mother, her children and finally as Monique Gasengayire (149) notes, "the battle between the luck of having survived and the guilt of having survived" (le combat entre la chance et la culpabilité de survivre).

Murekatete is born from a Hutu father and a Tutsi mother, and is therefore officially Hutu according to the Rwandan patrilineal system. The narration recalls incidents 
from her birth, childhood and education, and her marriage to a defrocked Tutsi priest. These are followed by the deaths of her moderate Hutu father and Tutsi husband before the genocide, her mother during the genocide, and finally her two Tutsi children during an attempt to flee from the country. She alone survives, but is mistaken for a Tutsi, attacked and left for dead, only to be "brought back to life" (ranimée) by Venant, an exiled Tutsi soldier (47). The remainder of the story tells of her life with Venant, who becomes her husband, and the effects of the genocide on their lives. Their attempt to come to terms with their past is unsuccessful and the story ends with her kind, patient, loving husband resorting to alcohol and drugs, raping her, thus giving her AIDS, and eventually abandoning her.

Murekatete is portrayed as being unable to resume her life after the genocide: "Because I am not dead, I must live. Upon waking up, I find that I am as distraught as I was the night before [...] Every morning, I put one foot in front of the other and I don't know if I am moving forward or backward" (47). ${ }^{13}$ The themes of death, loss and 'undoing of the self' permeate her narrative. Her comments show that she is familiar with the experience described by Semprun (26) of "passing through death". In her text, Ilboudo portrays death as an inopportune, ubiquitous presence, not natural death that happens to us all, but "unnatural death" that "collectively" "mows down the healthy", the young and the innocent. (34). ${ }^{14}$ Murekatete appears to be 'predetermined' to die and this impression does not leave her even after miraculously surviving the genocide. At her birth, her family wants to bury her because she appears to be stillborn, and only on the insistence of her mother is she spared and eventually starts breathing: "I was not born to live. I died at birth. The small grave was already dug. Everybody was ready for my funeral. Only my mother clung to the crumpled little corpse, refusing to let it be buried" (11). ${ }^{15}$

In opposition to this discourse of death personified, the narrator talks of rebirth and renewal, but these attempts are sadly soon whittled down to mere survival. Even when she attempts to embrace life, death haunts her, "prowling" around her "jealously", destroying "everything that (she) love(s)" (Elle rôde autour de moi et détruit tout ce que j'aime, 22). Her apparent capacity for what she calls "regeneration" (15) and for being "resurrected", a "miracle" (16) that takes place at two separate times in her life, seems to be limited to the physical sphere: "But Venant came, he saved me. Yet, what should have been a second life has been until now mere painful survival!" (22) ${ }^{16}$ Ilboudo evokes the image of a wandering shadow, a dead carcass, in order to depict the loss associated with trauma: "My life ended one day in June 1994 [...] Thanks to Venant, my carcass was brought back to life. But ever since, I wander around, like a shadow, a shadow of myself" $(45-7) \cdot{ }^{17}$ When Venant offers to take her to see a psychiatrist, she reacts vehemently: "So you think I've lost my marbles? You think that I am nuts? That I am crazy?" "Tu penses donc quej'ai perdu les pédales ? Tu penses que je suis dérangée? Que je suis folle?" 47). 
In both the story and the form of narration chosen by the author, evidence and signs of traumatic memory are present. The storyline is constantly subverted in terms of time and tense. These distortions, as well as its fragmented and repetitive mode, demonstrate the non-linear, associative working of traumatic memory and at the same time does what Ursula Tidd (423) would call "bear(ing) witness to the unexperienced experience of death". Ilboudo's text imitates these phenomena when Murekatete is plagued by a recurring dream, a nightmarish flashback to the time of an attack on her by a group of Hutu. In her dream they behave like a pack of dogs while she watches her head being severed from her body and her body hacked to pieces. The nightmare is repeated and slightly modified, triggered by events that remind her of the attack. She decides to go on a pilgrimage to all the genocide sites with her husband, in order to exorcise her nightmares and try to "understand" the genocide, not realising that Venant would be destroyed by this journey (52).

The character of Venant too is conceptualised as having experienced the trauma of genocide, the death of his mother, and being abandoned by his father who fled the country. However, he is endowed with a loving, kind and controlled manner of behaving. The secondary effects of trauma are brought to the fore when the author portrays a radical change in the conduct of this male character: when the couple undertake their pilgrimage and are confronted with the piles of bones and skeletons, his carefully constructed control disintegrates completely. He starts drinking heavily and rapes his wife, who up to that point has been so traumatised that she cannot give herself to him.

Murekatete senses that Venant has lost his confidence, not only in humanity, but in her too, as if he associates her with the monstrosities of genocide. This loss of faith is a blow that constitutes her most violent death experience: "Him, the author of my resurrection. This fatal blow was a bitter experience. This is a death I will never be able to recover from," she says (72). ${ }^{18}$

During the trauma of being raped by her husband she disassociates herself from her body, in order to look down on the scene from a distance, a scene in which they become two characters on a stage, and she the spectator:

I was paralysed. I didn't scream anymore, I no longer moved. I saw him going fiercely at my body with the sensation that it didn't belong to me. I did not recognise him either. From above the two characters, I stared at the unusual scene. The roaring of a wild animal coming from the man above the body that was not mine brought me back for a moment to reality. ${ }^{19}$

During this event, Murekatete no longer recognises herself or her husband.

This description is strangely reminiscent of the rape experience described by Tadjo in her text and discussed below, both incidents illustrating the notion of fragmenting of the self. Their characters display the loss of motivation to attempt to 
reconstruct the narrative of their lives, disrupted by trauma, the loss of sense of control over the events and subsequently the loss of self as described by Brison (44, 45). They portray the estrangement and alienation that results from such a traumatic experience, the reduction to an object, the damaging of the relationship between the self and the other, and even to the self. Ilboudo does not allow her character to experience the empowering value of narrative memory and its ability to help her to 'remake' herself.

Moreover, it is clear that Ilboudo's novel refrains from offering easy solutions or what Dominique LaCapra (254) would call a "redemptive narrative" as dénouement to her characters' deeply traumatised lives. The reader who expects a form of closure will therefore remain disappointed. Murekatete is in fact described by Monique Gasengayire (143-5) as "an (im)possible testimony" (un témoignage (im)possible) which transmits the "incapacity" of those who have survived, to tell the story. By creating a couple who is incapable of integrating the genocide experience into their life-story, Ilboudo transmits the failure of mimesis, as understood by Ricœur. In Freudian terminology, the couple remains trapped at a place of 'acting out': Murekatete, tormented by her recurring nightmares and Venant who develops an obsession with genocide sites and macabre stories. This leads to the logical conclusion of "ruin and desolation" in their lives-the psychological disintegration of Venant and of their relationship and trust, in each other and in themselves (ruine et désolation, Ilboudo 66). He leaves her and asks to be sent to a dangerous zone where people are constantly killed, thereby implicitly demonstrating his own death wish which is echoed by hers: "Venant has left, and the house, invaded by emptiness, is nothing but an echo of the nothingness of my life. Some days, I long to put an end to this nothingness. Only the fear of falling into the eternal void keeps me from doing so" (72). ${ }^{20}$

\section{Tadjo: Shadows of life and death}

Véronique Tadjo's literary account and travel diary, L'ombre d'Imana: voyages jusqu'au bout du Rwanda (2000), contains not only records of the author's encounters with Rwandans, but also her personal reactions to these stories. ${ }^{21}$ Her text tells a collective story, narrated by many voices, fragmented, associatively structured, alternating between past and present in both content and form. Many stories are incomplete, capturing a moment of the lives of individuals, providing a glimpse of the shadows of life and death which they inhabit.

We have chosen for the purposes of this analysis to focus on the narration of one character's experience. This story tells of the worst betrayal possible: a female character is raped by her own brother who is obsessed by her, an experience that destroys her, makes of her flesh a "prison", and her soul a "stranger" which she no longer recognises (63): 
When he spread her legs and entered her violently, she could not believe that what was happening to her was real. This must be in another life, another time. Her mind ceased to function.

Anastase left her lying there on the soiled bed.

She lay there prostrate, terrified.

She was ashamed. She felt dirty, repulsive. She no longer existed. (66, italics added)

Anastasie, like Murekatete undergoes a process of dissociating herself from her body and this turns out to be a self-destructive experience, her "first death" (66). Although "officially", Anastasie only dies a few years later, during the genocide, she ceases to 'exist' because of the trauma of rape: "Her mind detached itself from her body, floated in the room and hit the ceiling. That was her first death" $(66,67)$. This experience leads to an act of estrangement from her body and her mind: "She no longer recognised the inside of her body, felt a stranger to this heavy mass that was crushing her spirit" (63). Subsequently, the memory haunts and invades her and "hostile dreams" fill her nights (63).

Tadjo's literary recreation of the experience of rape embodies what we have established as being characteristic of traumatic events and the character's symptoms correspond to those of a victim who survived trauma: she is constantly tired, wants to close her eyes and sleep. Sleeping becomes a metaphor for death, and she longs to disappear into forgetfulness: "To disappear into oblivion, sail gently along, let herself be carried away by the underground stream" (63, italics added). Her thoughts, transmitted to the reader in a type of interior monologue, demonstrate her withdrawal from reality and time, her retreat into a safe world, a comforting past. It shows that a part of her has already died: "Shut the door to the shouts and murmurs of life, to the grating sound of the revolving door of time. A steady slide. Loss of consciousness. It was much better deep in her bed. More comforting, more peaceful" (63). These elliptic sentences suggest in an understated manner the victim's intense depression and rejection of life. They equally demonstrate the "impossibility of telling" the trauma (Kacandes 65).

Tadjo ingrains the marks of trauma in her protagonist: "Despite the passage of years, she still bore the wound in her flesh, in her hair, in her smile [...]. Instinctive terrors kept coming back to haunt her" (64). The author thus evokes the "body memories" of trauma referred to by Roberta Culbertson (179), in the sense that Anastasie has been unable to order them and "link emotion with event" in a way that would help her to work through the rape. In this character, the distinction between physical and mental trauma has become blurred. The author lets her experience despair, emptiness and the corresponding physical sensations of "drowning" and "sinking" and eventually a feeling that her body is "inhabited by Evil" — and that she will never 
escape from it (65). Thus she becomes an embodiment of the ineluctable horror of the genocide.

\section{SurVivantes: a life (self)-affirming testimony}

It is interesting to note in which way Esther Mujawayo's literary testimony corresponds to or differs from the literary configurations of the genocide by Ilboudo and Tadjo. Mujawayo's text is divided into three parts, the first dealing extensively with the survivors' need to tell their stories and the community's inability and unwillingness to listen to and believe them:

Today in Rwanda, people say to us: "We have spoken enough about this." [...] Noone explicitly asked us to keep quiet, we immediately sensed that we should keep quiet. [...] I could explain, in one sentence, why, as a survivor, one kept quiet after the genocide: one sensed that one was upsetting others. People couldn't bear to hear it; it was too much for them. Too much what, I don't know. You start to tell your story, you carry on telling it, and they refuse to listen, and this is terrible. They say: "It is too horrible." They say: "It is too much, too much ..." It is too much for whom? It is too much for me, or for you who listens? (Mujawayo and Belhaddad 20). ${ }^{22}$

As with Ilboudo and Tadjo, the form of narration adopted displays evidence of trauma, suggesting that although Mujawayo claims to be Vivante ("one who is alive"), rather than Survivante ("one who has survived"), the process of recovery is complex and perhaps never fully achieved. Belhaddad confirms that in spite of her reflexes as journalist to "polish" or condense Mujawayo's words, she deliberately chose to keep the "oral tone" in order to transmit the "hesitations" and the uncertainties, as well as the "associative" nature of her style which best translates the "internal chaos imprinted" in the hearts of all survivors (Mujawayo and Belhaddad 10-1). Belhaddad points out that when the genocide is evoked Mujawayo often slips from the imperfect into the present, thus disrupting conventions of tense. This can however be accounted for because the present is the "tense of trauma", a "suspended time", which does not afford the reader the comforting distance normally created by the past tense (11).

The second part which focuses on her life as Tutsi woman in Rwanda is written in a more linear fashion and describes Mujawayo's childhood, schooling and marriage before the genocide, the death of her husband and family members during the genocide, and her survival. The third part contains a reflection on Rwanda, ten years after the genocide. After the genocide, Esther completes a course in psychotherapy in Britain, where she has the opportunity of voicing her experiences before returning to her work at Oxfam in Rwanda. She becomes co-founder of an association for widows, AVEGA (its Kinyarwanda name Agahozo meaning 'dry one's tears'), who collectively 
and mutually help each other to work through their genocide experiences. Although the author was not raped during the genocide, she recounts the stories of some female survivors who were, and who share their stories with the other women from AVEGA. She demonstrates how for some of them, articulating their trauma brought relief, and for others it did not.

One day, a young girl Dafroza, raped at the age of fourteen, dares to share her story with the others for the first time. The disruption of tense, described by Belhaddad, and the presence of the unspoken is illustrated in the passage in which Mujawayo recounts this moment:

Dafroza started screaming like a wounded animal. She screams, gasps and talks at the same time, the death of her parents who were teachers, their house burning, and her brother whom she had to leave there, therefore guilty of ..., and how she had been "liberated", "barambohoje", she literally says it... and she ended off saying, that if she was alive now-alive for us means in good health-, she could never have children, and so she had only survived in order to die. (198-9)

This unburdening is not enough to save her, neither emotionally, nor physically, for she also has AIDS, and dies at the age of nineteen. Mujawayo writes: "She was so frail, so pretty, but, indeed, she had a sad expression in her eyes, sad enough to die from. In fact, she died from it, from her sadness, her illness, her despair. [...] How she screamed! She expressed her pain, she said it, but her pain was stronger than that. She died from it" $(198,199) .{ }^{24}$ In her brief narration of Dafroza's life, Mujawayo seems to blur the border between the physical and the mental consequences of Dafroza's traumatism. Did she die from sadness or from AIDS?

Through her testimony, the author also depicts the strategies some women from AVEGA adopt, not merely to 'survive', but to be 'fully alive' and the title SurVivantes reflects this choice. Mujawayo deliberately modifies the typography of the word, thus highlighting the term 'Vivantes' by using a capital letter in the middle of the word. This decision is confirmed in various instances: "One fights for a complete life-not just survival—you refuse to die inside, you refuse to become nothing but a victim" (77). ${ }^{25}$ Writing her testimony appears to be one of the strategies she uses to exercise this choice: "Mujawayo envisions testimony as a social practice of reconnecting with oneself and with one's community while remaining aware that the process of bearing witness to her trauma and loss does not amount to a definite catharsis [...] (Dauge-Roth 39). Alexandre Dauge-Roth (39) confirms that the "desire for connectedness through testimony must be envisioned in the first place as a performance of survival, an act through which the survivor attests publicly her social survival and reaffirms her ongoing and current presence despite the obliteration to which she has been subjected." 


\section{On life and survival}

Mujawayo's testimony, in spite of the presence of certain signs of trauma, forms a striking contrast to the stories of the two fictional protagonists, Murekatete and Anastasie. If we were to compare for example Murekatete and SurVivantes, and view both these 'stories' as authentic versions of a typical genocide experience (though, as we have established, one is indeed fictional), we observe that the main characters have gone through a similar traumatic experience; both are bereaved, female genocide survivors. ${ }^{26}$ Both have physically survived and were given a second chance to live after the ruin and desolation of the genocide. Both were given prophetic, life-giving names at birth by their fathers. Esther identifies strongly with her namesake from the Bible, whose task was to save her people: "I was always the brave one at home. It's because of my name" she says (J'ai toujours été la brave à la maison. C'est à cause de mon prénom, 18)

Both Murekatete and Esther experience their survival as a choice made for them, even imposed on them. Murekatete says: "[...] I should have died for good. Fate decided differently" (j'aurai dû mourir pour de bon. Le sort en a décidéautrement, 47), and Esther feels that the survivors had been "condemned to live" (condamnés à vivre, 34). After the genocide, however, both make a conscious effort to live: Murekatete says: "Every evening I make firm resolutions. I decide to make an effort, to get back the energy I used to have" (Chaque soir, je prends de fermes résolutions. Je décide de me secouer, de retrouver mon énergie de naguère. 47). Esther pronounces her choice as follows: "It so happens that I survived. Today, I live. My killers are not the ones who left me alive, it was I who from then on chose to live" (Il se trouve que j'ai survécu. Aujourd'hui je vis. Ce ne sont pas eux, mes tueurs, qui m'ont laissée en vie, c'est moi qui, désormais, ai choisi de vivore, 29).

Only Esther, the real-life victim though seems to truly have 'survived' the genocide and the reasons for this appear to be the following: Murekatete, who is isolated in many ways, is not portrayed as having a strong social support structure, refuses to come near a psychologist (47) and has only Specie, a friend to whom she talks, but who prefers to cheer her up with idle talk and the "latest gossip in the city" (les derniers potins de la ville, 62). In contrast to the fictional Murekatete, Esther becomes part of AVEGA and helps others to come to terms with their trauma, not only by encouraging them to tell their stories, but in supporting them in their physical and social needs. This sense of community is suggested by the feminine, plural form of the title: SurVivantes.

Furthermore, Esther's focus is more collective than personal. Belhaddad (10) remarks that for Esther it was important that her text goes beyond her own story, and Esther confirms this: "I don't have a deep need to tell my story. I'm a pragmatist, you know, if sharing my story can help others, then yes. But in a personal capacity, I don't know ... In any case, in Rwanda, each personal story has become History" (17). ${ }^{27}$ She 
describes AVEGA as a "forum" in which "individual suffering" (souffrances individuelles) is expressed through "collective voices" (voix collectives), and the "individual me supported by the collective us", who are in turn represented by a collective story (le moi individuel est soutenu par le nous collectif, Gallimore 15, 19). These women thus create opportunities of collective, active, 'authentic' listening where the group carries the individual, who is telling her story, through difficult moments. It is clear that Esther has a social advantage of being "reconnected with humanity" which her fictional counterpart does not have (Brison 45).

Esther displays a strong sense of agency towards the future which is related to her daughters: "But I hang on, for my daughters. They are my life [...] they are alive, in fact extremely alive" (Mais je tiens, pour mes filles. Elles sont ma vie. [...] elles sont vivantes, et même très vivantes, 31 ). This role is extended beyond her immediate family through her sense of responsibility towards her community, which is related to the vocation she received with her second name, Mujawayo and which means "servant of God" (la servante de Dieu, 24). She states: "There are a few survivors, and, for them, I will fight to the end [...] I believe it's not worth surviving in 1994 only to die stupidly afterwards, or to be completely weakened or run-down" $(14,17) \cdot{ }^{28}$ On the other hand, as protagonist, Murekate is a tragic figure: she has lost all her immediate family and has no children left who could provide her with a reason for living.

Mujawayo appears to have "remade" herself, and this is demonstrated by her regaining of her "voice" and her "subjectivity" (Brison 47), as depicted in her statement: "Moving from being condemned to live-something one felt strongly, if one survived a genocide-to choosing to live, that's the journey that I was on these last ten years" (Mujawayo and Belhaddad 29). ${ }^{29}$ When she speaks of survivors that go for therapy she says: "initially condemned to live, today they have chosen to live" (d'abord condamnés à vivre, aujourd'hui ils ont décidé de vivre, 30). This notion of overcoming by being reintegrated into a community and re-establishing her sense of agency contrasts sharply to Murekatete's despairing words that prove her inability to overcome the destructive experience of the genocide. This survivor is powerless to restore the connection between herself and humanity that has been severed, even to the point of being unable to give herself to her husband:

I was ashamed. Ashamed of waking him up each night with my indecent laughing. Ashamed of my incapacity to respond to his love. Without a word, Venant turned off the lamp and went back to bed. I felt his arm encircling me, in a vain attempt to protect me. I love Venant. From the bottom of my wounded heart. With all the strength of my mutilated body. I know that he loves me. But I am dead. I have been for a long time" (10). ${ }^{30}$

Her poignant affirmation: "I am dead. I have been for a long time", calls to mind Delbo's words, "I died at Auschwitz, but no one knows it" and Ernst van Alphen's (35) 
observation that "the basic feeling of being dead, or of continuing living as a dead person, is not narratable [...] a figurative reading does not acknowledge the unrepresentability of the experience [...]. On the contrary, it denies it [...]. Something has really died, not in a figurative, but in a most literal way".

The difference in the two texts lies in the fact that Mujawayo, who is herself a survivor, is in a position to trace in her testimony the journey towards redeeming the shattered life of the victim, whereas Ilboudo as intellectual witness only allows herself to demonstrate the consequences of trauma in the life of her protagonist and does not presume to suggest possible pathways to healing. ${ }^{31}$

\section{Conclusion}

The aim of this reading has been to compare the rendition of trauma and the 'death' experience in two fictional texts and a non-fictional one, written by three female African authors. In the narration of these women's stories, the authors underline the various symptoms of traumatic memory and the 'death' and rape experience as they manifest not only in their physical bodies, but also in their relationships and their minds. In all three texts these symptoms are transmitted through the textual strategies of interior monologue, fragmentation, and elliptical phrases which suggest the victims' struggle to articulate their experiences. When we consider the differences between the fictional and the non-fictional accounts, we discover that Ilboudo refrains from introducing aspects which empower survivors in the aftermath of genocide to overcome this experience, that Tadjo gives us glimpses of such possibilities, and only for some of her characters, and that Mujawayo's testimony in fact recounts the process as she experienced it in real-life. Her text suggests that the ability to move from a position of merely surviving to fully living is influenced by factors such as the opportunity to verbalise the experience, the social support structure, and society's (in)capacity to listen in an appropriate way to these stories. Mujawayo's account, based on her own experience, reclaims the subjectivity of the victim, and allows her to be re-connected to humanity through narration.

It is significant that the fictional characters of Murekatete and Anastasie, are portrayed not to have had the opportunity that Mujawayo had, of telling their stories to others who could respond appropriately, and this was indeed the case of many survivors. Brison (49) states that society lives with the unbearable "by pressuring those who have been traumatized to forget and by rejecting the testimonies of those who are forced by fate to remember". Thus the life-restoring experience of recovering and remaking the self that has been undone, destroyed, shattered by trauma was not granted to many of them. And so, many of them have survived the experience, but only some are fully alive. In Van Alphen's words: "The [death] experience continues" $(35) .^{32}$ 


\section{Notes}

1. “Mais le génocide n'a pas qu'une seule violence. Il n'a pas que la violence de la mort ou des tortures physiques. Il t'anéantit à l'intérieur de toi, il te fait ce que l'autre veut faire de toi: rien, même moins que rien. Même encore en vie, tu deviens inexistant." (153) Henceforth, all quotes from French texts are our translations unless otherwise stated. For long quotes, the original will be provided in endnotes.

2. The following texts were published as part of this literary project: The novels of Boubacar Boris Diop from Senegal, Murambi: le livre des ossements ("Murambi: the book of bones", 2000); of the Guinean writer Tierno Monénembo, L'aîné des orphelins ("The oldest orphan”, 2000); of Monique Ilboudo from Burkina-Faso, Murekatete ("Murekatete", 2000) as well as the symbolic account of Koulsy Lamko from Chad, entitled La phalène des collines ("A butterfly in the hills", 2002); the travel diaries/ accounts by Véronique Tadjo from Côte d'Ivoire, L'ombre d'Imana: voyages jusqu'au bout du Rwanda ("The shadow of Imana: travels in the heart of Rwanda", 2000) and Abdourahman A. Waberi from Djibouti, Moisson de crânes: textes pour le Rwanda ("Harvest of skulls: stories and essays for Rwanda", 2000); the poetry anthology written by Nocky Djedanoum from Chad entitled Nyamirambo! ("Nyamirambo!", 2000); the essay of the exiled Rwandan Jean-Marc Vianney Rurangwa, Le génocide des Tutsi expliqué à un étranger ("The genocide of the Tutsis explained to a foreigner", 2000) and genocide survivor, Vénuste Kayimahe's testimony, France-Rwanda: Les coulisses du génocide, témoignage d'un rescapé ("France-Rwanda: Behind the scenes of a genocide, testimony of a survivor", 2001).

3. "We initiated a task, even if it is up to the Rwandans themselves to take over with the distribution of books and circulation of shows etc." (Nous avons initié un travail, quitte aux Rwandais eux-mêmes à prendre le relais dans la diffusion des livres, des spectacles etc., Djedanoum \& Coulibaly 1).

4. For those who feel a sense of obligation to represent a traumatic event, even though they did not directly experience it, Geoffrey Hartman $(37,38)$ proposes the term "intellectual witness".

5. She has since co-authored another with Belhaddad entitled La fleur de Stephanie: Rwanda entre réconciliation et deni ("Stéphanie's flower: Rwanda between reconciliation and denial", 2006).

6. “Je ne sais pas si cette réaction chez moi relève de la fierté ou d'un instinct à tenir le coup. Je sais seulement qu'être vivante-vivante, plutôt que survivante, est une façon de les punir. C'est ma seule vengeance possible" (5).

7. This is Tidd's translation (408) of Semprun's expression avoir traversé la mort.

8. “Car la mort n'est pas une chose que nous aurions frôlée, côtoyée, dont nous aurions réchappé, comme d'un accident dont on serait sorti indemne. Nous l'avons vécue" (Semprun 121).

9. Tidd (407) refers to Semprun's writing as Holocaust "autothanatographies".

10. "On peut toujours tout dire, le langage contient tout [...] On peut tout dire de cette expérience [...]. Mais peut-on tout entendre, tout imaginer? [...]. En auront-ils la patience, la passion, la compassion, la rigueur nécessaires?" (Semprun 26).

11. For further discussion of the representation of rape in narrative texts within the context of the Rwandan genocide, consult Eleni Coundouriotis's (2013) insightful article which combines aspects of legal theory, testimonies and visual theory on this issue.

12. "Nous avons libéré les femmes Tutsi, nous avons libéré ces arrogantes..." (Mujawayo 196).

13. "Puisque je ne suis pas morte, je dois vivre. Au réveil, je me retrouve aussi désemparée que la veille. [...] Chaque matin, je mets un pied devant l'autre, et je ne sais si j'avance ou si je recule" (Ilboudo 47).

14. Our observation draws on the following excerpt: "La mort était partout. Une mort inhabituelle. Il n'y a rien de plus normal que la mort. Tout ce qui vit meurt un jour. [...] La mort anormale est celle qui fauche des êtres sains, dans la force de l'âge, des enfants en pleine croissance, des fotus à l'abri, dans le sein maternel. La mort n'est pas normale lorsqu'elle frappe collectivement des êtres qui n'aspirent qu'à vivre" (Ilboudo 34).

15. "Je n'étais pas née pour vivre. Je suis morte à la naissance. La petite tombe était déjà creusée. Tout le monde était prêt pour mon enterrement. Seule ma mère se cramponnait à ce petit corps fripé, refusant de le laisser ensevelir" (Ilboudo 11).

16. "Mais Venant est arrivé, il m'a sauvée. Pourtant, ce qui devait être une seconde vie n'est jusque-là qu'une pénible survie! " (Ilboudo 22).

17. “Ma vie s'est arrêtée un jour de juin 1994 [...] Grâce à Venant, la carcasse a été ranimée. Mais depuis, je déambule, comme une ombre, l'ombre de moi-même" (Ilboudo 45-7).

18. "Lui, l'artisan de ma résurrection. Je ressentis cruellement ce coup fatal. Je ne me remettrai jamais de cette morte-là" (Ilboudo 72, italics added). 
19. “J'étais tétanisée. Je ne criais plus, je ne bougeais plus. Je le vis s'acharner sur mon corps avec la sensation que ce n'était pas le mien. Je ne le reconnaissais pas, lui non plus. Au-dessus des deux personnages, je scrutais cette scène insolite. Les rugissements de bête fauve de l'homme au-dessus du corps qui n'était pas le mien me ramenèrent un instant à la réalité" (Ilboudo 69).

20. "Venant est parti, et la maison, envahie par le vide, ne résonne plus que du néant de ma vie. Certains jours, me prend l'envie de mettre un terme à ce néant. Seule la crainte de tomber dans le néant éternel me retient." (Ilboudo 72)

21. We have used Véronique Wakerley's translation entitled The Shadow of Imana: Travels in the Heart of Rwanda (2002) throughout the article. All page numbers mentioned refer to the translated text and not the original text.

22. "Au Rwanda on nous dit aujourd'hui: “On en a assez parlé." [...]. Personne ne nous a explicitement demandé de nous taire, on a tout de suite senti qu'il fallait se taire [...]. Je pourrais dire, en une phrase, pourquoi, rescapé, on s'est tu après le génocide : on sentait qu'on dérangeait. Les gens ne pouvaient pas supporter d'entendre, c'était trop pour eux. Trop quoi je ne sais pas. Tu commences à raconter, raconter, et ils n'acceptent pas d'écouter, et c'est terrible. Ils disent: 'C'est trop horrible'. Ils disent : 'C'est trop, trop...' C'est trop pour qui ? C'est trop pour moi ou pour toi qui écoutes ?" (Mujawayo and Belhaddad 19-20).

23. "Dafroza s'est mise à hurler comme une bête bléssée. Elle hurle, hoquette et raconte en même temps, la tuerie de ses parents instituteurs, et sa maison brûlée, et son frère qu'elle a dû laisser, donc coupable de ..., et comment elle a été "libérée", "barambohoje", comme elle le dit littéralement... et elle a fini en disant que si elle était vivante maintenant-vivante chez nous, signifie en bonne santé-, elle ne pourra plus jamais avoir d'enfant et qu'elle n'a donc survécu que pour mourir..." (198-9).

24. "Elle était si frêle, si jolie, mais, en effet, avec un regard triste, triste à mourir. Elle en est morte, d'ailleurs, de sa tristesse, de sa maladie, de son désespoir. [...] Comme elle a hurlé! Elle a sorti son mal, elle l'a prononcé mais son mal a été plus fort. Elle en est morte" (Mujawayo and Belhaddad 198, 199).

25. "On se bat pour une vraie vie - et pas seulement une survie - on refuse de mourir dedans, on refuse de n'être que des victimes" (Mujawayo and Belhaddad 77)

26. One could have also compared them with Tadjo's protagonist, which we are unable to do here due to obvious constraints.

27. "Je n'éprouve pas de besoin profond de raconter mon histoire. Je suis une pragmatique, tu sais: si témoigner de mon parcours, ça peut être utile, alors oui. Mais à titre personnel, je ne sais pas... De toute façon, au Rwanda, chaque histoire personnelle est devenue de l'Histoire" (Mujawayo and Belhaddad 17).

28. "Il y a quelques survivants et, pour eux, je vais me battre jusqu'au bout [...]. Je trouve que ce n'est pas la peine de survivre en 1994 pour mourir bêtement après, ou être complètement affaibli ou complètement à plat" (Mujawayo and Belhaddad 14, 17).

29. "Passer de la condamnation à vivre—qu'on a fort éprouvée, quand on avait survécu au genocideau choix de vivre, c'est le chemin que j'ai moi-même fait pendant ces dix ans" (Mujawayo and Belhaddad 29).

30. "J'avais honte. Honte de le réveiller chaque nuit avec ce rire indécent, honte de mon incapacité à répondre à son amour. Sans un mot, Venant éteignit la lampe et se recoucha. Je sentis son bras qui m'entourait, dans une vaine tentative de protection. J'aime Venant. Du plus profond de mon cœur meurtri. De toutes les forces de mon corps mutilé. Je sais qu'il m'aime. Mais je suis morte. Depuis bien longtemps" (10).

31. It is important to note that there are other protagonists in Tadjo's text who do suggest such possible pathways, but that we have not been able to explore within the scope of this article.

32. "The camp experience continues...." (Van Alphen 35).

\section{Works cited}

Bal, Mieke, Jonathan V. Crewe and Leo Spitser. Acts of Memory: Cultural Recall in the Present. Eds. Mieke Bal, Jonathan Crewe and Leo Spitser. Hanover: UP of New England, 1999.

Brison, Susan J. "Trauma Narratives and the Remaking of the Self." Acts of Memory: Cultural Recall in the Present. Eds. Mieke Bal, Jonathan Crewe and Leo Spitser. Hanover: UP of New England, 1999. 39-54.

Caruth, Cathy. Trauma: Explorations in Memory. Baltimore, Maryland: John Hopkins UP, 1995. 
Coundouriotis, Eleni. "'You only have your word:' Rape and testimony." Human Rights Quarterly 35.2 (2013): 365-85.

Culbertson, Roberta. "Embodied memory, transcendence, and telling: recounting trauma, re-establishing the self." New Literary History 26.1 (1995): 169-95.

Dauge-Roth, Alexandre. Writing and Filming the Genocide of the Tutsis in Rwanda: Dismembering and Remembering Traumatic History. Plymouth: Lexington Books, 2010.

Delbo, Charlotte. Le convoi du 21 janvier. Paris: Minuit, 1965.

Djedanoum, Nocky and Maïmouna Coulibaly. “ 'Nous avions l'obligation morale d'aller jusqu'au bout': entretien de Boniface Mongo-Mboussa avec Nocky Djedanoum et Maïmouna Coulibaly.” 1 Sept 2000. Africultures 12 Jan 2012. <http://www.africultures.com/php/index.php?nav=article\&no $=1463>$.

Gallimore, Béatrice R. "Souffrances individuelles et voix collectives: la stratégie orale des témoignages des femmes au Rwanda." Cultures Sud January-March 2009: 15-22.

Gasengayire, Monique. "Murekatete, un témoignage (im)possible." Dix ans après : réflexions sur le génocide rwandais. Eds. Rangira B. Gallimore and Chantal Kalisa. Paris: L’Harmattan, 2005. 14360.

Hartman, Geoffrey H. "Shoah and Intellectual Witness." Partisan Review 65.1 (1998): 37-48.

Herman, Judith Lewis. Trauma and Recovery. New York: Basic Books, 1992.

Ilboudo, Monique. Murekatete. Bamako: Le figuier; Lille: Éditions de Fest'Africa, 2000.

Kacandes, Irene. "Narrative Witnessing as Memory Work: Reading Gertrud Kolmar's a Jewish Mother." Acts of Memory: Cultural Recall in the Present. Eds. Mieke Bal, Jonathan Crewe and Leo Spitser. Hanover: UP of New England, 1999. 55-74.

LaCapra, Dominick. Writing History, Writing Trauma. Baltimore, Maryland: The John Hopkins UP, 2001.

Laub, Dori. "Truth and Testimony: The Process and the Struggle." Trauma: Explorations in Memory. Ed. Cathy Caruth. Baltimore, Maryland: John Hopkins UP, 1995. 61-75.

Mujawayo, Esther \& Souâd Belhaddad. SurVivantes: Rwanda, dix ans après le génocide. La Tour d'Aigues: Éditions de l'Aube, 2004

Ricœur, Paul. Temps et récit: tome I. Paris: Éditions du Seuil, 1983.

Semprun, Jorge. L'écriture ou la vie. Paris: Gallimard, 1994.

Tadjo, Véronique. L'ombre d'Imana: voyages jusqu'au bout du Rwanda. Arles: Actes Sud, 2000.

. The Shadow of Imana: Travels in the Heart of Rwanda. Trans. Véronique Wakerley. Portsmouth: Heinemann, 2002.

Tidd, Ursula. "The Infinity of Testimony and Dying in Jorge Semprun's Holocaust Authanatographies." Forum of Modern Language Studies 41.4 (2005): 407-17.

Van Alphen, Ernst. "Symptoms of discursivity: experience, memory, and trauma." Acts of Memory: Cultural Recall in the Present. Eds. Mieke Bal, Jonathan Crewe and Leo Spitser. Hanover: UP of New England, 1999. 24-38.

Van der Kolk, Bessel A and Onno van der Hart. "The intrusive past: the flexibility of memory and the engraving of trauma." Trauma: Explorations in Memory. Ed. Cathy Caruth. Baltimore, Maryland: John Hopkins UP, 1995. 158-82. 